\title{
A STUDY ON DIRECTIONAL BASIC WIND SPEED FOR THE WIND RESISTANT DESIGN OF TRANSMISSION TOWERS
}

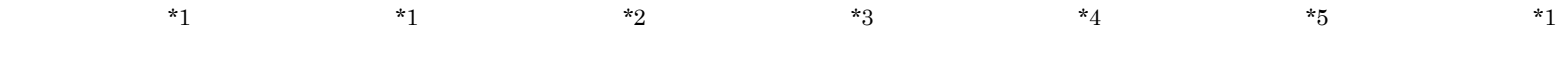 \\ Motoyuki YAMAZAKI , Tomomi ISHIKAWA , Takeshi OHKUMA , Yukio TAMURA , \\ Tomoki KITASHIMA , Hideharu NAKAMURA and Hisashi KATO
}

\section{SUMMARY}

Since the wind load is critical for the design of transmission lines, it is important to assess the design wind speed reasonably at construction sites. Wind loads acting on the transmission tower usually vary greatly by direction because of the structural characteristics. However, in the current design method of transmission towers, non-directional basic wind speed is applied in Japan, and therefore in many cases this may result in overestimation. In this paper, a method to estimate directional basic wind speed for the transmission tower design is proposed. The return period of the directional wind speed is estimated keeping the same non-exceeding probability of occurring stresses as the current design method. Then directional basic wind speeds at meteorological stations are determined by comparing with the typhoon simulation results.

Keywords: transmission tower, directional basic wind speed, return period, typhoon simulation

1 はじめに

送電線路は電力輸送に関わる重要な社会基盤構造 物であり，十分な信頼性・安全性とともに，建設コス 卜の観点から高い合理性が要求される . 送電線路は架 渉線とこれを支持する送電用鉄塔から構成される構造 物であり，構造上，風荷重が支配的荷重になることが 多い.また，送電線ルートや建設用地確保の制約上， 山岳部や沿岸部など風荷重条件の厳しい地点に建設さ れることが多いのか現状であり，建設地点の諸条件に 応じて合理的に設計風速を見積もることが重要となる． 送電用鉄塔は架渉線を支持する構造であるため，これ
に作用する風荷重は強風時の風向によって顕著に変化 すると同時に, 年最大風速は対象地点の地理的位置, 周辺地形や粗度の状況, 台風の通過経路およひ季節に よる強風の卓越風向の違い等から, 風向によって大き く異なるものと考えられる.しかしながら, 現在の耐 風設計手法1),22では, 風向を考慮して荷重算定を行うこ ととしているものの, 設計風速については風向にかか わらず一律の值としている．風向を考慮しない全風向 の年最大風速から求められた風速によって設計する手 法は，耐力面では安全側評価を与えるものの，建設コ ストの面では必ずしも合理的とは言えない .
*1 (財) 電力中央研究所

Central Research Institute of Electric Power Industry

*2 神奈川大学

Kanagawa University

*3 東京工芸大学

Tokyo Institute of Polytechnics
*4 東京電力株式会社

Tokyo Electric Power Company

*5 広島大学

Hiroshima University 
そこで, 本研究の位置付けを明確にするため, 設計 風速と風向別設計に関する既往の規・基準, 研究例を 以下に整理する.

耐風設計で用いられる設計風速の設定には，文献 2),3)に見られるように，官署で観測された年最大風速 を極值分布にあてはめることによって，所定の再現期 間に対する風速を求める方法が広く適用されている． しかしながら, 観測された風速は, 強風の発生要因に よる分類がなされていないこと，観測期間が有限であ ることや観測データにサンプリングエラーを有するこ となどの課題を有している .

風向別設計に関して,ASCE7-024)では風向係数とい う概念を導入し, 全風向風速から求めた設計風速に対 し風向係数を乗じることで, 風向別風速による低減効 果を考慮している.また ,Australian Standard ${ }^{5)} て ゙ は ，$ 観測データの豊富な主要都市周辺を対象に風向別基本 風速を与えるものとし, 光れ以外の地域では全風向風 速に対する低減係数の適用領域を定めることで風向別 風速の効果を反映している，一方，日本においては風 向別風速を取り入れた設計手法は, 土木・建築分野の 規・基準においても未だ例が無いものの, 風向別風速 に関する研究は積極的に行われている.神田ら ${ }^{6)}$ は外 装材を対象として風向特性を考慮した設計風速の最適 化手法を提案し，建設コストの面から炎の合理性を示 している．また藤野ら 》風向別再現期間風速算定に は風向と風速に依存性があることや，短い観測期間の データから求めた風向別再現期間風速の誤差の定量化 を試み, 風向別風速の有利性を示している.さらに白 石・松本ら ${ }^{8)}$ (比較的短期間における 3 時間毎の風観 測記録を基に, 極值分布によって求めた再現期間風速 と, Weibull 分布からの再現期間風速の比を風向別に 台風係数として求め, 風向別の強風特性の評価を行っ ている.また日本建築学会では，建築物荷重指針の改 定にあたり風向係数の導入を視野に入れた風向別設計 の体系化を検討している9).

このような状況を踏まえ，本論文では送電用鉄塔の 合理的かつ実用的な荷重評価手法の確立を図ることを 目的として，風向別基本風速を求めるための方法論の 提案と風向別基本風速の定量化を試みるものとした .

風向別基本風速を策定する場合の問題点は，第一に 風向別基本風速の再現期間を設定する方法, 第二に風 向別に再現期間風速を精度よく求めるための方法が挙 げられる．本論文ではこの二点について検討した結果 を中心に述べる．
第一点については, 従来, 再現期間は風向を考慮し ない年最大風速に対して定めていたが, 送電用鉄塔の 荷重効果の特性を考慮することにより，風向別風速の 再現期間について検討した .この際, 風向別に風荷重 効果を評価して得られる全体の安全性が, 従来と同程 度の安全性レベルを維持することを基本とした 。

第二点に関しては, まず気温によって張力荷重の変 化が大きい送電線路の特性から，観測值を季節 (高温 季・低温季) で区別し，さらに高温季にあっては観測 值の成因 (台風および非台風) により区別して再現期 間風速を算定した . また台風の観測值については，風 向別とすることによるデータ不足から，信頼性の高い 統計值を算出するのは困難と判断し, 観測值と台風シ ミュレーションのキャリブレーションによって風向別 基本風速を定量化するための方法を検討し, 新たな方 法論の提案を行った . さらに, 弚の方法を実際の官署 に適用した場合の風向別基本風速の算定結果について 示した。

\section{2 風向別基本風速の再現期間に関する検討}

\section{1 風荷重効果を考慮した再現期間の考え方}

送電用鉄塔のように風向によって荷重効果が大き く変化する構造物の場合, 風向別に設計風速を設定す ることにより，設計の合理化が期待できる .

まず，代表的な架線状態における送電用鉄塔の風向 特性について示すこととする.ここでは, 全風向一律 の平均風速としたときの, 各風向における最下節の主 柱材の 4 脚に作用する軸力を算定した . 送電用鉄塔の 主柱材は通常, 軸圧縮力が支配的であるため, 軸圧縮 力の最大值て評価した . 算定にあたっての計算条件は Table 1の通りであり 粗度区分に応じた上空風高さ， べき指数, 乱れの強さ, および乱れのスケールは文献 3)に準拠した . 検討に用いた鉄塔モデルを Fig.1 に示 す.

最下節の主柱材の軸力算定は, 風の乱れによって生 じる規模効果, 共振効果を考慮した等価静的風荷重算 定法 ${ }^{10)}$ によるものとし, 架線状態は, Fig.2 に示すよ うに, 径間長, 架線の水平角度の組み合わせによる 6 ケースとした .なお, 風向は北を 0 度とし時計回りに 測った角度で表す。

Fig.3 は各ケースの架線状態において算定した最下 節の軸圧縮力の最大值に対する軸力の比率を示したも のである . 架線に水平角度を有しないケース[1] , [2] は, 0 度および 180 度付近の風向の時に軸力の最大值 
を示す .一方, 架線に水平角度を有するケース[3]〜 [6] は, 0 度風向では風圧荷重と架渉線の張力荷重の方向 が逆方向となるため軸力が低下し，180 度付近では最 大值を，45 度，315 度付近で極大值を示すような特徵 的な挙動を示す.このように送電用鉄塔は, 同じ風速 であっても風荷重効果が風向によって大きく変化する ことから，荷重効果の小さい風向では大きい風向に比 べて設計強度に対する年超過確率への寄与率が小さく なる、したがって，このような影響を考慮して再現期 間を定めることにより 鉄塔ごとのばらつきの少ない， より合理的な耐風設計が可能になるものと考えられる．

送電用鉄塔の耐風設計にあたって参照される JEC- $\left.127-1979^{2}\right) に は$, 全風向年最大瞬間風速の 50 年再 現期間に対する地域別速度圧が示されている．乥こで， 再現期間 50 年から想定される安全性のレベルが, 送 電用鉄塔の設計軸力に対する年超過確率 0.02 に相当 するものとし，これと同等の安全性を確保するための 風向別風速の再現期間について検討した . なお，再現 期間 50 年の意味する安全性のレベルについては, 設 備重要度, 建設コスト, 維持管理等の観点から今後十 分な議論が必要である。

また，風向別風速の分割数を設定する必要があるが， 風向は 8 風向として検討を行うものとした .これは本 論文の手法を現在想定している実務設計入適用する場 合の設計者に対する便を考慮して判断したものである .

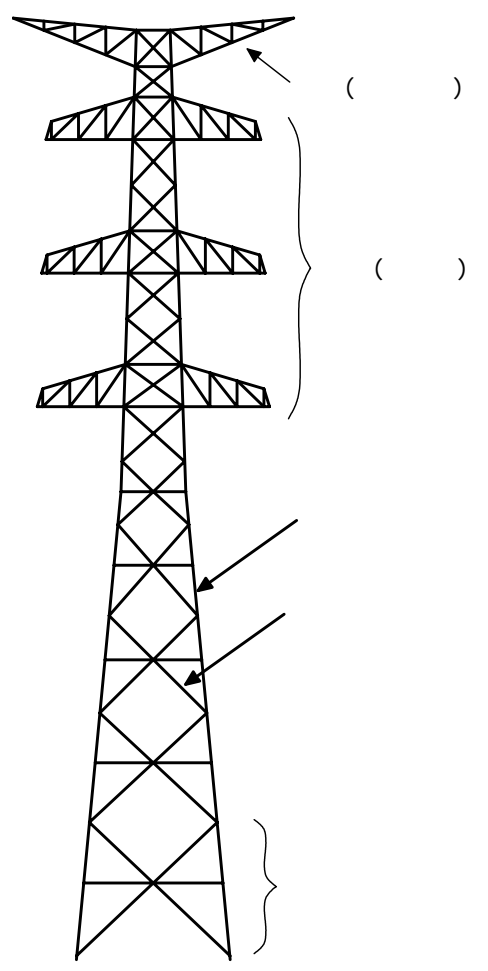

Fig. 1 検討用鉄塔モデル

General view of a transmission tower model
Table 1 算定条件

Calculation conditions

\begin{tabular}{|c|c|}
\hline 対象鉄塔 & 500kV，2回線，耐張型，鋼管鉄塔 \\
\hline 鉄塔高さ & $77.5 \mathrm{~m}$ \\
\hline \multirow{2}{*}{ 架渉線種類 } & 架空地線 OPGMR90mm ${ }^{2}$ ，単導体 \\
\hline & ACSR $810 \mathrm{~m}^{2}$ ，4導体 \\
\hline \multirow{2}{*}{$\begin{array}{l}\text { 架渉線張力 } \\
\text { (風速40m/s作用時) }\end{array}$} & 架空地線 $33.3 \mathrm{kN} /$ 条 \\
\hline & $49.0 \mathrm{kN} /$ 条 \\
\hline 10m高さ風速 & 40m/s (粗度区分 II, 全風向一律) \\
\hline ディケイファクタ & 水平横方向: 10, 鉛直横方向: 10 \\
\hline
\end{tabular}

[1]

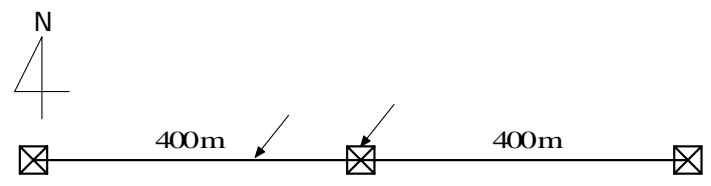

[2]

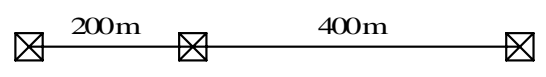

[3]

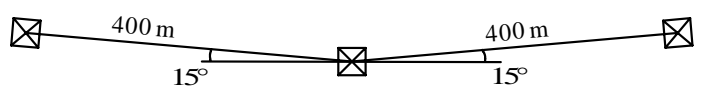

[4]

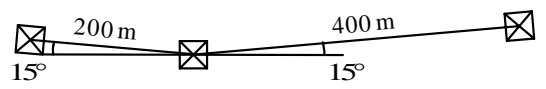

[5]

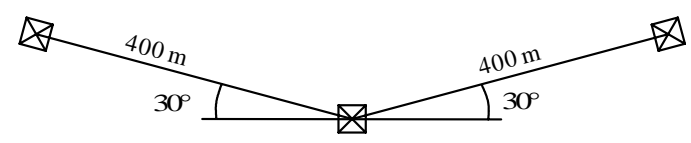

[6]

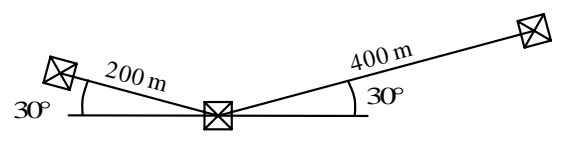

Fig.2 架線状態ケース

Arrangement cases of towers and cables

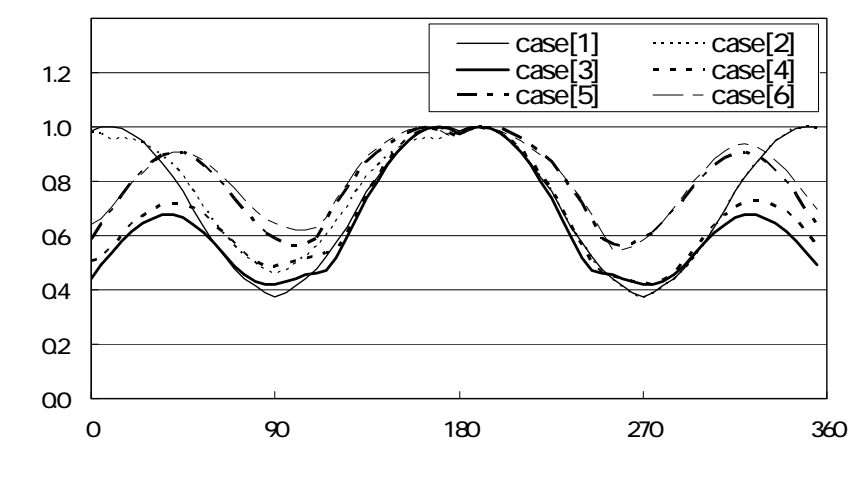

Fig.3 風向による最下節主柱材の軸力の比率 Ratio of axial forces of the lowest posts by wind direction

\section{2 風向別風速の再現期間の算出手順}

送電用鉄塔の軸力の再現期間 50 年に相当する風向 
別風速の再現期間を設定するための検討手順は以下に 示す通りであり，検討フローを Fig.4 に示す．

(1) 風向別風速の再現期間を $R$ 年 (例えば 50 年) と して仮設定する

(2) 観測結果等に基づいて予め設定した風向別風速の 分布形に応じ，再現期間 $R$ 年に対する 8 風向別風 速值 $V_{i}$ を設定する．ただし $i$ は風向を示し， 1 か ら 8 をとる.ここで設定した風速値 $V_{i}$ が各 8 風向 を代表する風速値となる．

(3) 8 個に分割した風向のうち, 各風向を中心とした $\pi / 4$ の角度内において最大の荷重効果を有する 角度 $\theta_{i}$ を見出す．具体的には，風向毎に設定した $V_{i}$ によって，角度をパラメータに最下節の主柱材 軸力を算定し，4 脚の軸圧縮力の最大値を $N\left(V_{i}, \theta_{i}\right)$ として算定する .

(4) (3)で求めた 8 個の軸力 $N\left(V_{i}, \theta_{i}\right)$ の最大值を求め, この值を再現期間 $R$ 年に対する風向別風速に対す る設計軸力 $N_{\text {max }}$ として設定する .

(5) Gumbel 分布に基づき, 長期間 ( $T$ 年間) の年最 大風速值を作成する．再現期間 $R$ （非超過確率は 1-1/R）とこれに対する風速值 $V_{i}$, Gumbel 分布 の直線の傾き $1 / a$ から風向毎に $T$ 年分の年最大風 速値 $V_{i j} \quad(j=1 \sim T)$ を算定する.

$$
\begin{aligned}
F_{j} & =1-\frac{j}{T+1} \\
y_{j} & =-\ln \left(-\ln F_{j}\right) \\
V_{i j} & =b+\frac{y_{j}}{a}
\end{aligned}
$$

ただし, 係数 $a$ は初期設定值とし, 係数 $b$ は非超 過確率 $1-1 / R$ と光のときの風速値 $V_{i}$ より定まる.

(6) (5)で設定した風向毎の $T$ 年分の年最大風速值 $V_{i j}$ に対応する角度 $\theta_{i j}$ を設定する.ここでは，角度 $\theta_{i j}$ は, 各風向ா/4の角度内において風向による風速 の発現確率に偏りが無く一樣分布に従うものと仮 定し，式(4)により求める。

$$
\begin{aligned}
\theta_{i j} & =\frac{\pi}{4}\left(i+r_{j}-\frac{1}{2}\right) \\
r_{j} & : \text { 一樣乱数 }\left(0<r_{j}<1\right) \\
j & : 1 \sim T
\end{aligned}
$$

(7) (5)で設定した風速値 $V_{i j}$ と，(6)て設定した角度 $\theta_{i j}$ による風荷重から，最下節の主柱材の軸力 $N\left(V_{i j}, \theta_{i j}\right)$ を算定し，風向毎に設計軸力 $N_{\text {max }}$ を超
過する個数 $n_{i}$ を積算する .

（8）設計軸力に対する年超過確率 $P$ を式(5)により算 定する .

$$
P=\sum_{i=1}^{8} \frac{n_{i}}{T}
$$

（9）設計軸力の年超過確率 $P$ と目標としている年超過 確率とを比較する . 最下節の主柱材軸力の年超過 確率の最低值が 0.02 を下回る場合, (1)の風向別風 速の再現期間 $R$ を設定し直し, 最下節の主柱材軸 力の年超過確率の最低值が 0.02 となる再現期間 $R$ を見出す．

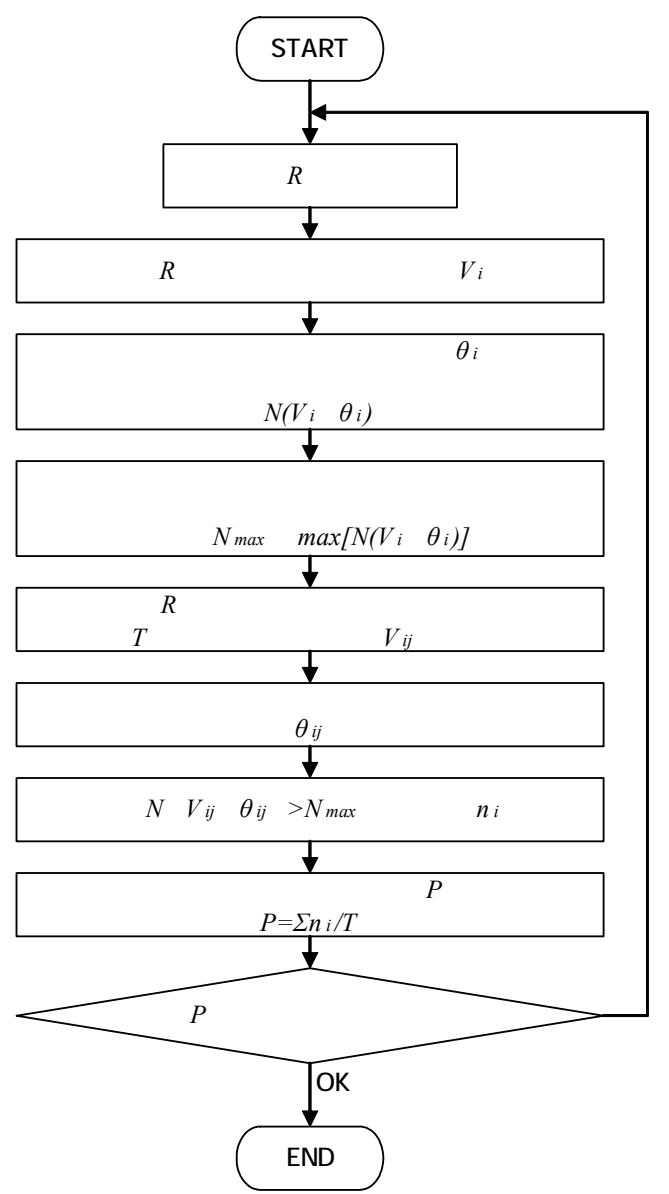

Fig.4 風向別再現期間検討フロー

Flow chart for the estimation of return period of directional basic wind speed

\section{3 風向別風速の再現期間の検討条件と検討結果}

ここでは，2.1に示す鉄塔を対象とし，Fig.5 に示す 鉄塔位置と風向との関係を仮定して風向別風速の再現 期間を検討することとした . 架線状態は Fig. 2 に示す 径間長と水平角度を組み合わせた代表的な 6 架線ケー スとした . また，地上高さ $10 \mathrm{~m}$ 位置の平均風速の分 布は, Fig.6 に示すとおりであり, 全風向で風速が一 律となる分布ケース(1), 相対する 2 風向の風速が突出 する分布ケース $(2) \sim(5)$,特定の風向の風速が大きい分 
布ケース(6)〜(13), 特定の風向の風速が小さいケース 分布(14)〜(21)の計 21 ケースとした. .架線状態と風速 分布を組み合わせた検討ケースの一覧を Table 2 に示 す.各風向あたりの風速データは Gumbel 分布に従う 10000 個のデータとした . また Gumbel 分布の直線の 傾き $1 / a$ は, 対象地点の地理的位置や風向によってば らつきを有し，著者らによる官署の調査結果によれば 平均值は 3.0 , 標準偏差は 1.4 程度となっているが, ここでは代表値として 3.0 と 4.0 の 2 ケースとした .

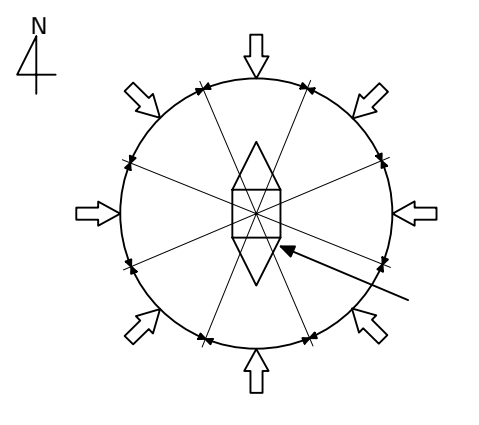

Fig.5 鉄塔と風向の配置

Location of tower and wind directions
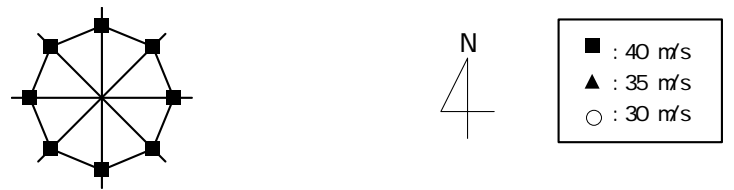

(1)
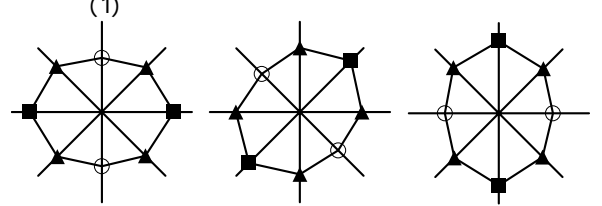

(4)

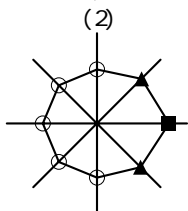

(3)
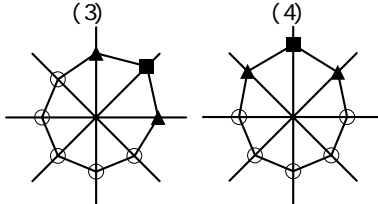

(8)

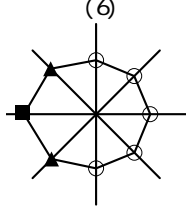

(10)
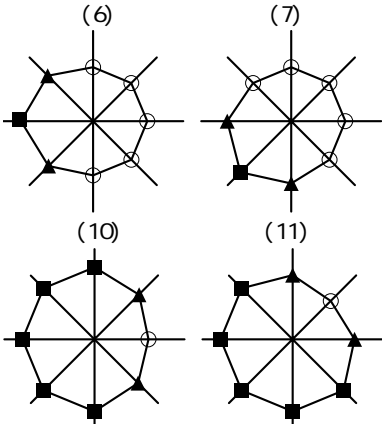

(11)

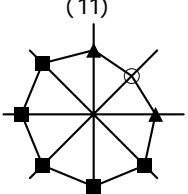

(15)

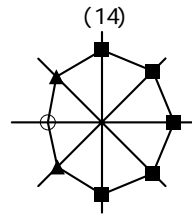

(18)

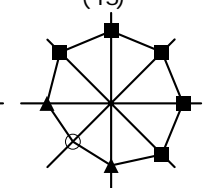

(19)

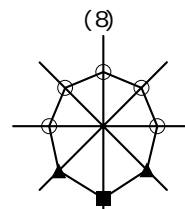

(12)

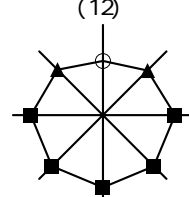

(16)

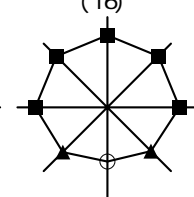

(20)

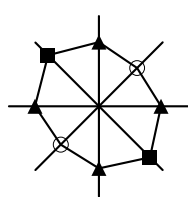

(5)

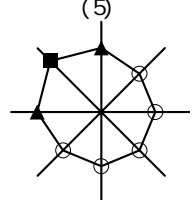

(9)

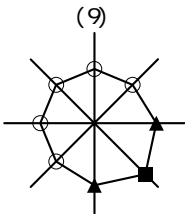

(13)

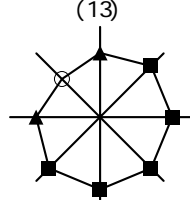

(17)

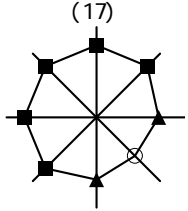

(21)

Fig.6 風向別風速の分布ケース一覧 Cases of directional wind speed distribution

Table 2 検討ケースー覧

Cases of study for return period

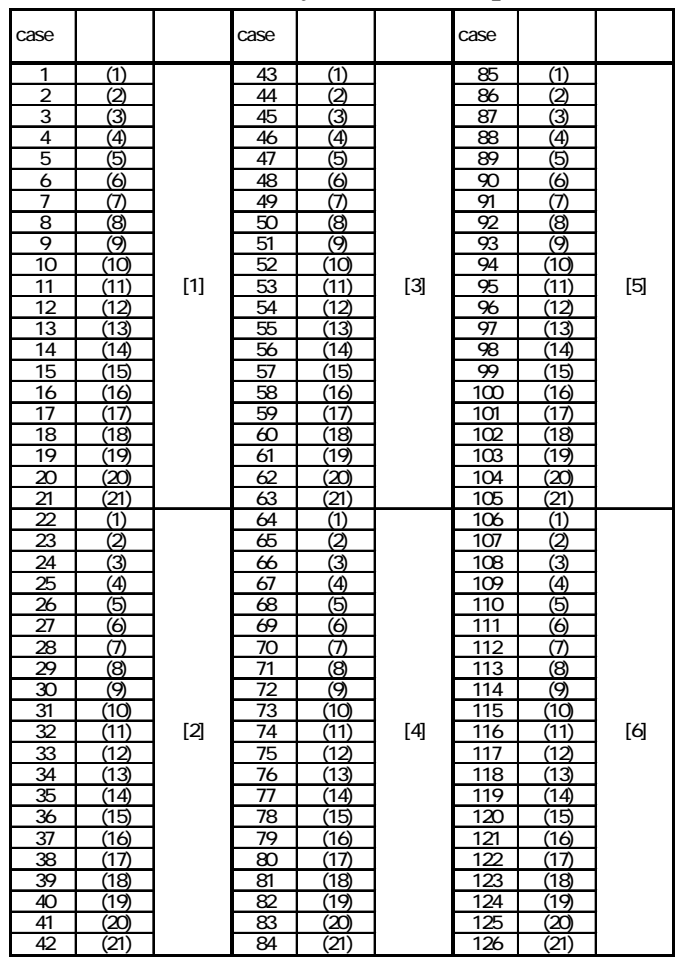

8 風向別風速の再現期間を 100 年 , 150 年 , 200 年 とした場合の設計軸力に対する年超過確率の検討結果

(年超過確率の逆数である再現期間にて表示)を Fig.7 に示す . 同図からもわかるように, 再現期間は風向特 性，架線状態に大きく影響を受ける．年超過確率が， 概ね 0.02 以下 (軸力の再現期間が 50 年以上) となる のは, 8 風向別風速の再現期間を 150 年以上とした場 合となっている .

再現期間の特徵を整理すると以下の通りである .

1） 再現期間が相対的に長くなるケースは, 荷重効果 が大きい風向の風速が大きく, 荷重効果の小さい 風向の風速が小さい場合．

2）再現期間が短くなるケースは,1)と正反対の場合 . および風向による荷重効果の影響が相対的に小さ い直線鉄塔で各風向の風速に差異のない場合 .

例えば架線ケース[3]で風向・風速分布が(11)(12)(13) となるケース 53,54,55 は,南からの風による荷重効果 が大きく，かつ南からの風速が大きいため，再現期間 は長くなっている．一方，架線状態は同じで風向・風 速分布が(7)(8)(9)となるケース 49,50,51 は, 南からの 風による荷重効果が大きいが, 南からの風速が小さい ため，再現期間は概ね前者の $1 / 2$ 程度となっている。 また, 架線ケースが[1][2]となる直線鉄塔は, 風向・風 速分布が(1)(14)の場合，すなわちケース 1,14,22,35 で は再現期間は総じて短くなっている . 


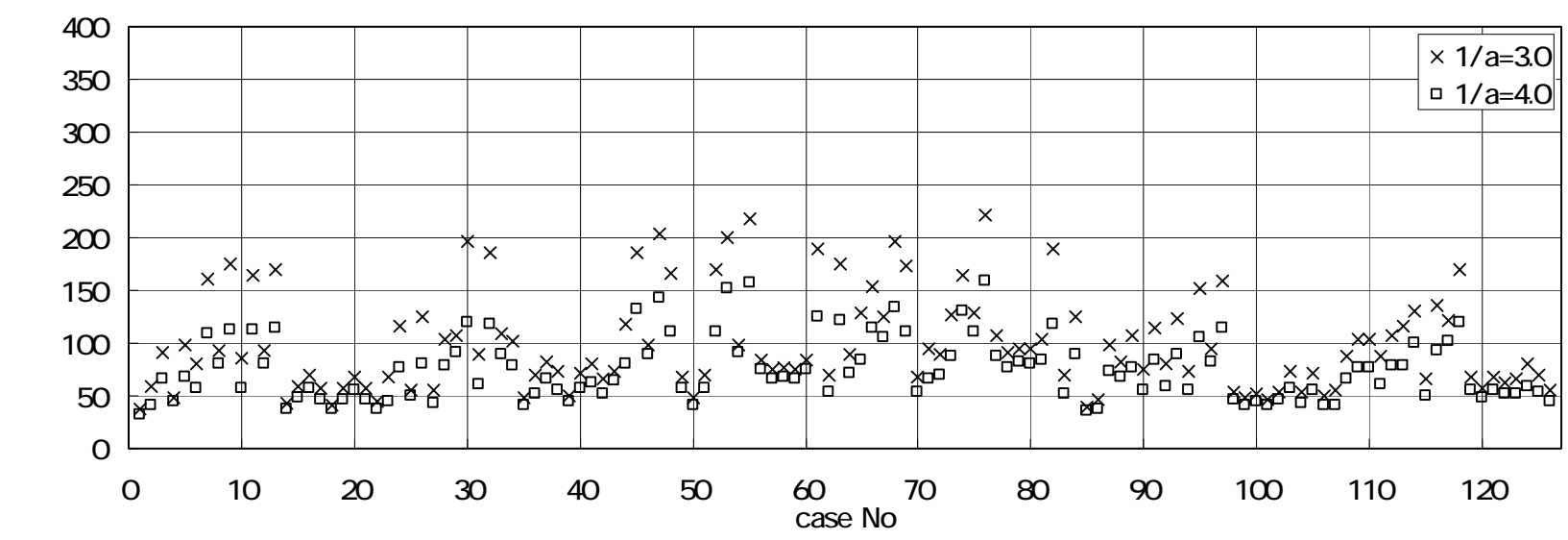

a）風向別再現期間を 100 年として設定した場合

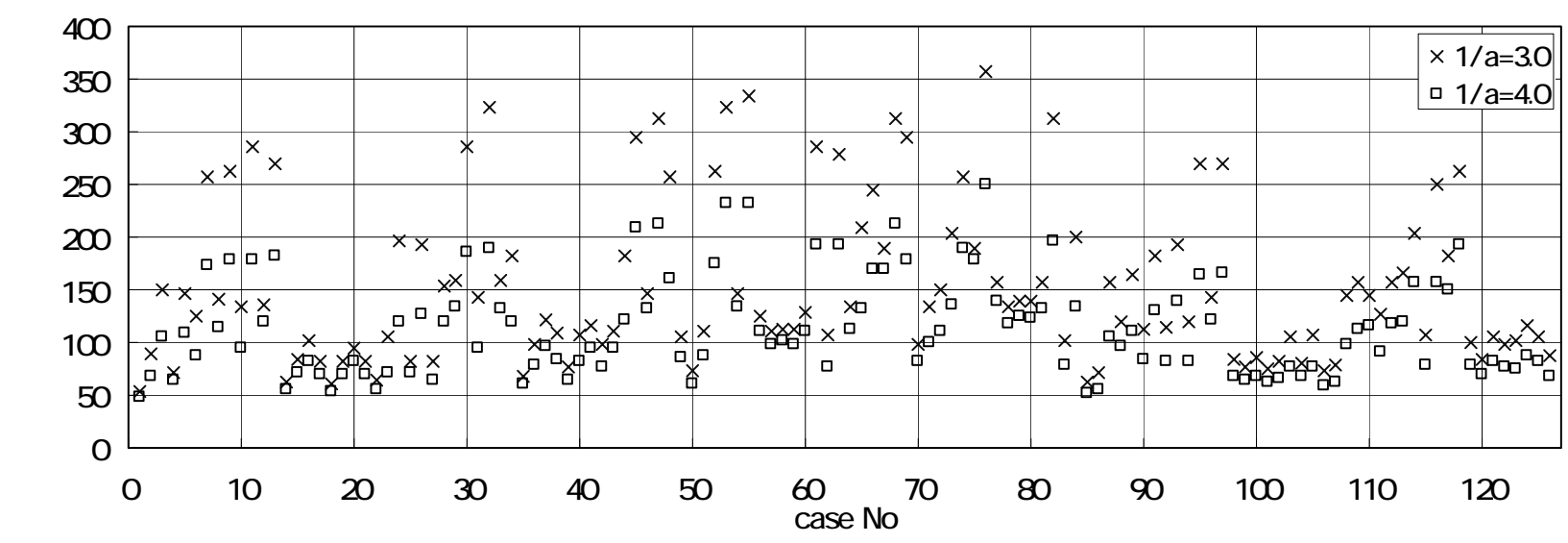

b）風向別再現期間を 150 年として設定した場合

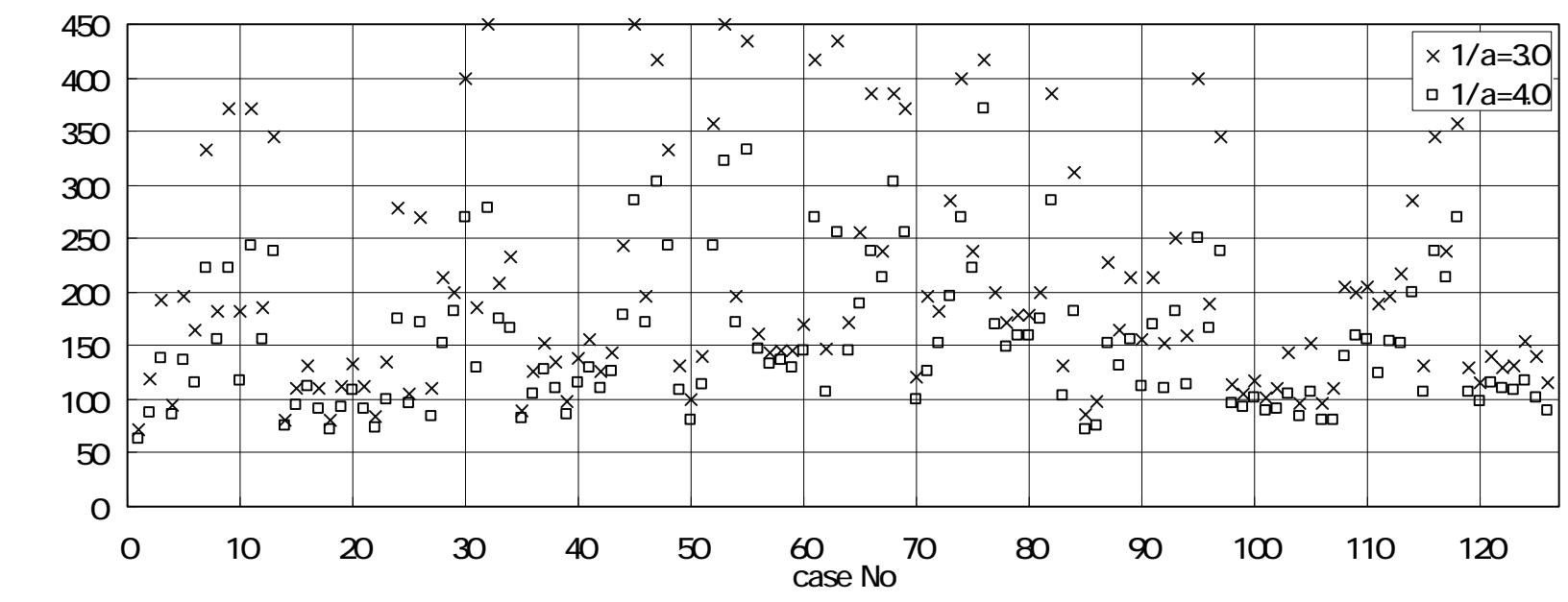

c）風向別再現期間を 200 年として設定した場合

Fig.7 設計軸力の年超過確率 (再現期間表示)

Return periods of design axial forces

\section{4 風向別基本風速の上限值の設定}

8 風向別風速の再現期間を 150 年として設定した場 合, 前述のとおり架線条件, 風向・風速分布の組み合 わせによって設計軸力に対する年超過確率に大きなば
らつきを生じている．年超過確率の小さな，すなわち 再現期間が大きくなるケースの再現期間を小さくする ことができれば目標とする安全性により近づけること が可能となると考えられる.このため, 風向別風速が 
全風向の 50 年再現期間風速を超える風向について， この風速によって上限を設けた場合と設けない場合に ついて比較することを試みた 。

全風向 50 年再現期間風速は, 各 8 風向の風速の発 現確率は互いに独立と仮定し, 全風向風速の年超過確 率が 0.02 となる風速值として算出した. 傾き $1 / a=3.0$ の場合, 全風向の 50 年再現期間風速は以下のように なる。

(1) 風向別風速の分布ケース(1) : $42.9 \mathrm{~m} / \mathrm{s}$

(2) 風向別風速の分布ケース(2) (5): $39.8 \mathrm{~m} / \mathrm{s}$

(3) 風向別風速の分布ケース(6) (13) : $38.0 \mathrm{~m} / \mathrm{s}$

(4) 風向別風速の分布ケース(14) (21): $41.7 \mathrm{~m} / \mathrm{s}$

したがって, 全風向 50 年再現期間風速を上回るの は，(2)の分布ケース(2)〜(5) と (3)の分布ケース(6)〜(13) の風速 $40 \mathrm{~m} / \mathrm{s}$ か設定された風向となる . また，同樣に 傾き $1 / a=4.0$ の場合, 全風向の 50 年再現期間風速は，

(1) 風向別風速の分布ケース(1) : $43.8 \mathrm{~m} / \mathrm{s}$

(2) 風向別風速の分布ケース(2) (5) : $40.3 \mathrm{~m} / \mathrm{s}$

(3) 風向別風速の分布ケース(6) (13) : $38.3 \mathrm{~m} / \mathrm{s}$

(4) 風向別風速の分布ケース(14) (21) : $42.5 \mathrm{~m} / \mathrm{s}$

となり，全風向 50 年再現期間風速を上回るのは, (3) の分布ケース(6)〜(13)の風速 $40 \mathrm{~m} / \mathrm{s}$ 蔎定された風向 となる．

再現期間 150 年の風向別風速に対して, 全風向 50 年再現期間風速による上限を設けない場合 $(\times$ 印) と， 上限を設けた場合 (○印) の年超過確率 (再現期間表 示) を比較した結果を Fig.8 に示す.全風向 50 年再現 期間風速による上限を設けた場合，特に風向別風速の 分布ケース(6)〜(13)については, 設計風速の低減率が 大きいことから再現期間の低減が大きいが, 目標とし ている 50 年を下回るものは認められない .
風向別風速の再現期間を 150 年としたときの年超過 確率は, Gumbel 分布の直線の傾き, 全風向 50 年再 現期間風速による上限の有無により以下のように整理 される .

(1) 全風向 50 年再現期間値による上限無しの場合 傾き $1 / a=3.0: 52 \sim 357$ 年 傾き $1 / a=4.0: 48 \sim 250$ 年

(2) 全風向 50 年再現期間値による上限有りの場合 傾き $1 / a=3.0: 52 \sim 312$ 年

傾き $1 / a=4.0: 48 \sim 212$ 年

全風向の 50 年再現期間風速により上限値を設けた 場合，再現期間が長く評価されていたケースに，光の 低減が見られたものの，新たに 50 年を下回るものは 見られず，再現期間のばらつきを小さくできることが わかった . 以上の結果から, 本論文では 8 風向別基本 風速の再現期間は 150 年とし, かつ全風向の 50 年再 現期間風速による上限值を設けることとして以降の展 開を図るものとする .

なお，ここでは Gumbel 分布の直線の傾き $1 / a$ は代 表値を用い，風向別風速の分布ヶースは限られたもの としているが, 地点毎, 風向毎に個別に設定すること により，風向別風速の再現期間を求めることが可能で あり，今後の課題として位置づけられる．また，風向 別風速の再現期間は各風向で一律として荷重を評価す る方法を提案しているため, 架線状態, 風向別風速の 分布によって, 設計軸力に対する発生軸力の年超過確 率がばらつきを有することとなる．これに対して，個 別の建設地点を対象に, 風向別風速の確率分布，風向 別の荷重効果が明確であるならば, 風向毎に異なる風 向別風速の再現期間を設定することで, 目標とする年 超過確率に合致させるような荷重評価も可能であろう．

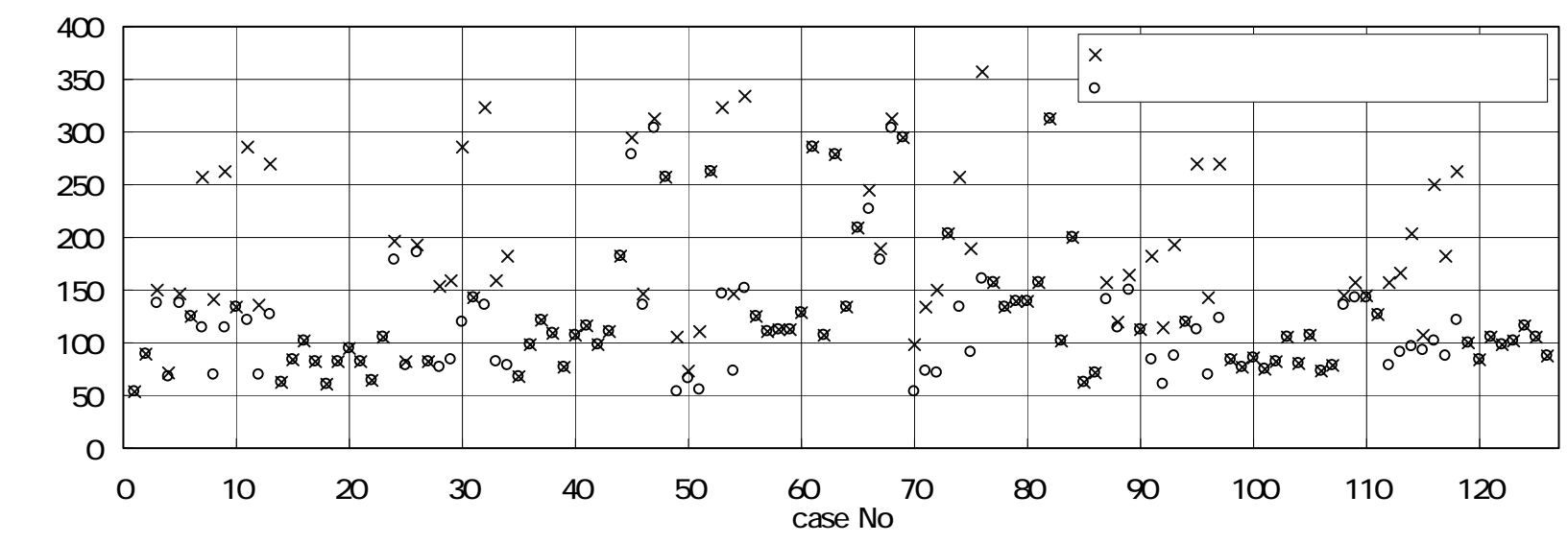

a）風向別風速の Gumbel 分布の傾きが 3.0 の場合

Fig.8 風向別風速の再現期間を 150 年としたときの設計軸力の年超過確率 (再現期間表示) (続く) Return periods of design axial forces, when return period of directional wind speed is 150 years 


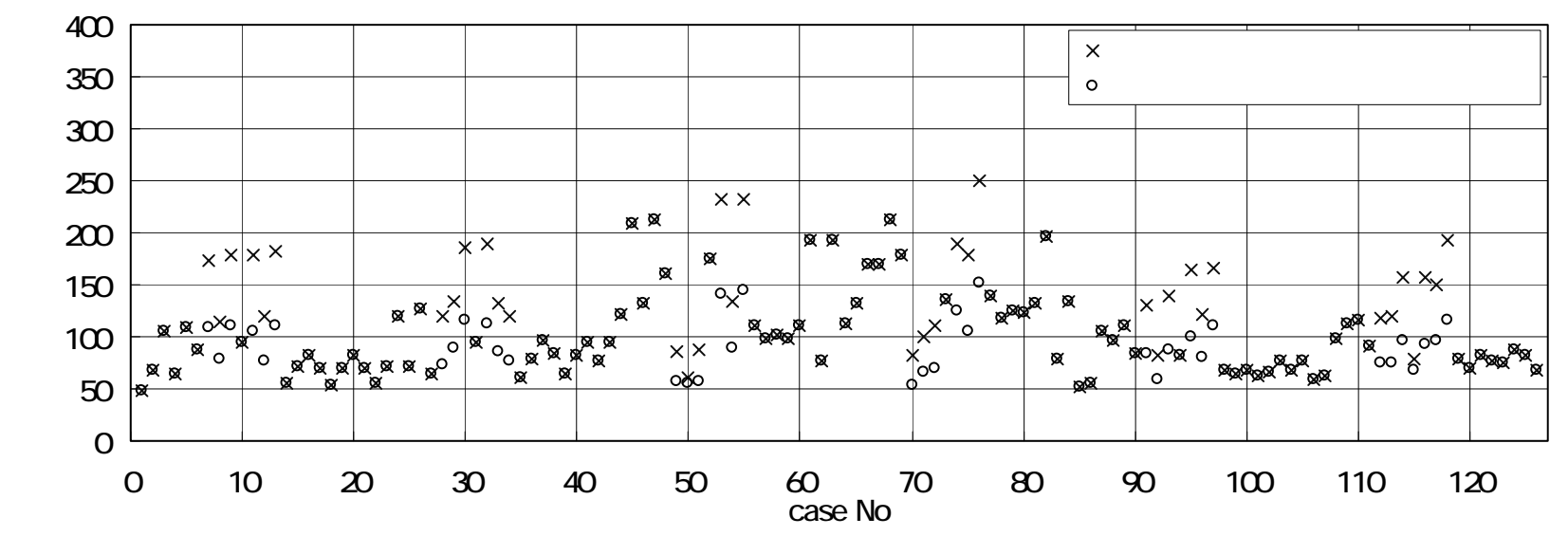

b) 風向別風速の Gumbel 分布の傾きが 4.0 の場合

Fig.8 風向別風速の再現期間を 150 年としたときの設計軸力の年超過確率 (再現期間表示)

Return periods of design axial forces, when return period of directional wind speed is 150 years

\section{3 官署位置における風向別基本風速の算定}

\section{1 風向別基本風速算定の考え方と算定手順}

本論文において風向別基本風速は, 地表面粗度区分 II，地上高さ $10 \mathrm{~m}$ における 10 分間平均風速の 8 風向 別 150 年再現期間風速と定義する.さらに, 風向別基 本風速は，建設地点における台風の襲来頻度や季節風 の発生頻度 , 緯度・経度や, 山脈・半島あるいは海か らの距離などの大規模な地形の影響を反映し，周辺 $10 \mathrm{~km}$ 四方程度を代表するものとして，以後の議論を 展開する.

送電線は鉄塔と架渉線からなる構造物であり，架渉 線張力による荷重は温度の影響を強く受けることから， 通常，気温の条件を考慮した設計がなされている。し たがって，一年を，夏から秋にかけての季節に発生す る強風 (主として台風を想定) を考慮した期間, およ び冬から春にかけての季節に発生する強風（主として 冬季季節風を想定）を考慮した期間に分類し，文献 2) に従い,乥れ高温季, 低温季と称することとした。

基本風速の算定にあたり，官署における風向・風速 の観測データが基本となるが, 風向別に基本風速を定 める場合には, 高々 50 年程度の官署における観測デー タ，特に台風時データについては，8風向別とするこ とによるデータ不足は明らかであり，信頼性の高い統 計值を算出することは難しい．このため，例えば ASCE7-023)では，地域によっては基本風速を定める時 にハリケーンの観測データは使用しないこととし，八 リケーン・シミュレーションによって定めるよう提唱 している，一方で，観測データは，実測值であるため 一般社会に対する強い説得力を有していることも確か
である

また, 極値統計解析上の問題点として, 実際の官署 における観測記録が , 理論上漸近するはずの極值の漸 近線に従わないことがしばしばみられ，再現期間の外 挿に疑問がもたれている.例えば,Gomes \& Vickery ${ }^{11)}$ は, 複数の成因からなる年最大風速の確率分布は複数 の極值分布の合成になることを示し，従来の一つの極 值分布を用いる場合には再現期間の大きな範囲では， 過小評価になる可能性を指摘している。

本論文では，以上に述べた課題に対処するため，高 温季については, 官署観測データを成因別 (台風と非 台風）に整理することにより，データの統計解析上の 問題点を排除し,さらに台風時データについては, 文 献 12),13)に示された台風モデルによるモンテカルロ シミュレーション (以下, 台風シミュレーション) に よって得られた風速值を，観測值でキャリブレーショ ンするという併用方法を提案する .

台風シミュレーションは, 台風の確率モデルの妥当 性, 傾度風から地上風に変換する際の精度などの課題 が挙げられ, シミュレーション結果の絶対値評価に対 する信頼性には若干疑問がある.しかしながら台風モ デルを規定する物理量 (台風の発生頻度, 進行速度, 最大旋衡風速半径, 中心気圧低下量など) は, 偶然性 の大きい風速の観測記録よりは信頼性が高いこと, 長 期間 (例えば 10000 年)のシミュレーションが可能で, サンプリングエラーを回避できることなどの利点を有 する．このため，本論文では，台風の襲来頻度の少な い地域を除き，各風向相互の風速值の相対関係につい ては，観測データよりは信頼性が高いものと判断し， 
観測データと台風シミュレーションから求めた全風向 の 150 年再現期間風速の比率 (観測データ/台風シミ ユレーション) を, 台風シミュレーションから求めた 風向別 150 年再現期間風速の分布形に掛けあわせる方 法を採ることとした .これにより，地域的な風速レべ ルは観測データに, 風向別風速の分布形は台風シミュ レーションに基づいた設定となり，観測データと台風 シミュレーションの長所を取り入れた設定が可能であ ると判断した。

また, 官署の風向によっては再現期間風速が台風時 よりも非台風時の方が上回る場合もあることから，い ずれか大きい方を採用することとした .ただし , 台風 時の再現期間風速と非台風時の再現期間風速力接近す る場合は, 本手法で求めた風速值は再現期間が過小評 価となる可能性があり，この手法の課題の一つとして あげられる.今後, 台風シミュレーションの絶対值評 価に対する信頼性が向上すれば，台風時と非台風時の 風速の確率分布を合成することで , 所定の再現期間に
対する風速を求めることも可能であろう .

官署における風向別基本風速の算定手順は， Fig.9 に示すフロー図のとおりである . 高温季は , 観測デー タに基づく全風向 150 年再現期間風速を $V_{2}$,台風シミ ユレーションによる全風向 150 年再現期間風速を $V_{4}$ とし，これらの比率 $\alpha=V_{2} / V_{4}$ をとり，これを台風シ ミュレーションによる 8 風向別 150 年再現期間風速 $V_{5 \_i}$ に乗じる. 次に観測データに基づく非台風 150 年 再現期間風速 $V_{3_{-} i}$ と $a V_{5_{-} i}$ を比較し大なる方を兴の風 向の值 $U_{o_{-}}$とするが, 上限值として観測に基づく全風 向 50 年再現期間風速 $V_{l}$ を設定する . なお, 台風シミ ユレーションの結果を用いない官署は, 観測データの みにより設定する .

一方, 低温季は, 観測データに基づく全風向 150 年 再現期間風速を $V_{2}$ とし，観測データに基づく風向別 150 年再現期間風速 $V_{3 i}$ を炎の風向の值 $U_{o_{-} i}$ とするが, 上限値として観測に基づく全風向 50 年再現期間風速 $V_{I}$ を設定する .
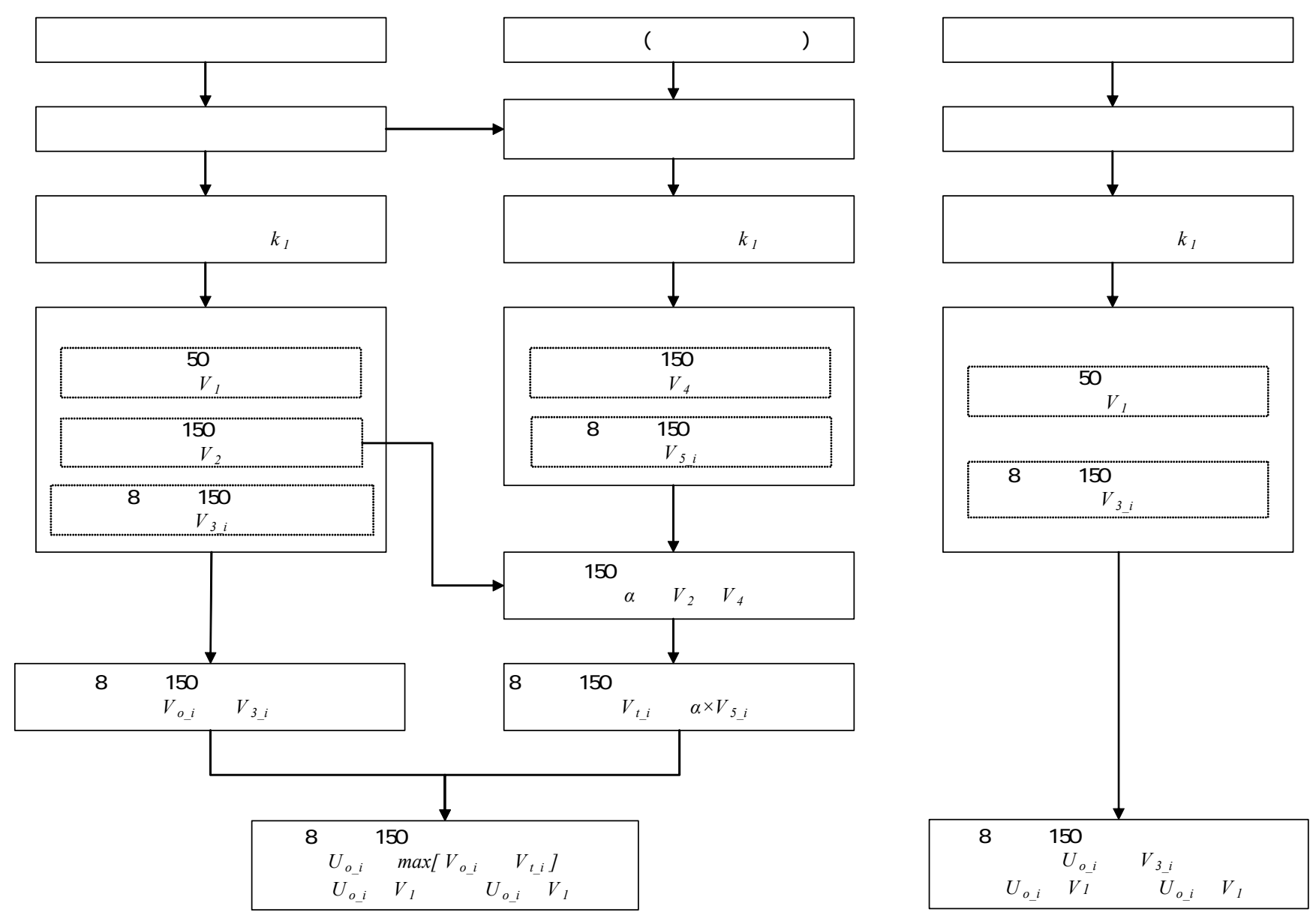

Fig.9 風向別基本風速の設定フロー

Flow chart for the estimation of directional basic wind speeds 
また，官署における観測データは，直近の小地形の 影響を受けている場合, 官署の周辺地域を代表する風 速となっていない可能性がある .このため, 風向別に 算定した小地形による風速の割り増し係数 $k_{l}$ (ただし $\left.k_{l} \geqq 1.0\right)^{14)}$ によって風速を割り戻すことにより，直近 の小地形による増速影響を除去し，色険側の評価にな る可能性を排除した .

\section{2 官署における風観測デー夕の処理方法}

官署の風観測値によって求める再現期間風速 $V_{1}, V_{2}$, $V_{3_{-} i}$ の具体的な算出方法と炎の結果について, 以下に 述べる。

（1）利用した資料と風向・風速データの抽出

利用した資料と抽出したデータは以下の通りであ る。

(1) 気象庁月報から，日最大風速と炎の時の風向を 抽出 (1951-1960).

(2) 気象庁年報から，3 時間毎の正時風速と炎の時の 風向 (1961-1990)，毎正時風速と炎の時の風向

(1991-2000) および日最大風速と光の時の風向 (1961-2000) を抽出 .

(3) アメダス観測年報から, 官署位置における毎正 時風速と炎の時の風向 (1976-1990) を抽出. こ れにより 1976〜1990 年までの 3 時間毎の正時 風速データを補完 .

(4) 月表, 日原簿から, 台風接近時の 6 時間毎の正 時風速と炎の時の風向を抽出 (1951-1960). こ れにより 1951〜1960 年までの日最大風速を補 完.

（2）風観測データの処理手順と処理方法

a) 各 16 風向の季別年最大風速の抽出

各年の毎日の毎正時 (または 3 時間毎の) 風速お よび日最大風速から，風向毎に季別最大值を抽出し， 季別年最大風速とする .なお, 上記処理には後述す る風速計高さ補正を先に見込み，高さ $10 \mathrm{~m}$ 位置の 風速として扱う.

b) 風速值の補正 (測器, 地表面粗度, 風速計高さ) 風速計の变遷に伴う風速の測器補正は, 風車型風 速計を基準風速計とし，データの均質性を確保した . 1951〜1960 年は風速計が 4 杯式であるため，風洞 実験公式を考慮する前の測定値に戻した值に 0.91 を乗ずるものとした . また，1961〜1974 年は風速 計が 3 杯式であり，風速値に 0.91 を乗ずるものと した。
次に，風速計の高さや周辺の地表面粗度は官署毎 に異なることから，風速計高さの基準化(地上 $10 \mathrm{~m}$ ) と地表面粗度の基準化(粗度区分II)を行った . 地表 面粗度区分に対する平均風速の鉛直分布は, 文献 3) に示されている式と定数を使用し, 粗度に応じた上 空風高さとべき指数で表すこととした .

また，官署周囲の地表面粗度の経時変化について は, 最近の昭和 60 年次の他に, 昭和 50 年次及び昭 和 40 年次における官署周りを撮影した写真を利用 して検討した .これより年次別の 8 風向別の各地表 面粗度を周辺地域の地表面の状況に応じて, 文献 3) に示されている地表面粗度区分 $(I \sim \vee)$ と, さら に光の中間値も加えて, 合計 9 区分として地表面粗 度を読み取った .16 風向毎の粗度を求めるにあたっ ては, 読み取った 8 風向と一致しない中間にある風 向は, 両隣の地表面粗度の平均值とし, また各年は 各年次間を線形内挿した。なお，昭和 40 年次以前 ならびに昭和 60 年次以降は地表面粗度区分は一律 とした .

c) 16 風向別データから 8 風向別データへの集約

風向の設定は 8 風向としているが, 16 風向のとき の中間に位置する風向，例えば NNE は 8 風向の時 の $\mathrm{N}$ 又は $\mathrm{NE}$ として分離することができないため， 観測された 16 風向のうち, 隣り合う風向を含めた 3 風向の最大值を, 当該風向の風速として集約するこ ととした .したがって , 統計的な厳密性は失われる ものの, 厳密な意味で 8 風向に分割して求めた風速 值よりも相対的に大きめの值を与える可能性があ る。

d) 直近の小地形の影響を除去するための風速補正

直近の小地形の影響を除去するため, 各風向の風 速値を風向毎に設定した小地形による割り増し係 数 $k_{l}$ により除することとした .風向毎の $k_{l}$ の設定に あたっては，50m メッシュの標高データを使用し， まず官署位置を中心に水平方向 1 度毎に $k_{l}$ を 360 度算定し,8風向に分割した 1 風向の 45 度内の最低 值を求め, 弚の風向の代表値として採用した。

e) 全風向の季別年最大風速の抽出

上記処理によって抽出, 補正された風向別の年最 大風速から，風向を考慮しない全風向の季別年最大 風速を抽出した。

f) 全風向および各風向の季別再現期間風速の算出

年最大風速の再現期間值を算定するにあたり， Gumbel 分布に従うものとし，観測データの経験的 
非超過確率は，Thomas の方法を用いた 。

台風時以外のデータは, 最大風速 $U$ の非超過確率 は最小自乗法により Gumbel 分布にあてはめ, 再現 期間風速を求めることとした .

一方, 台風時データは松井ら ${ }^{15)}$ の手法に従い, 台 風時の最大風速 $U$ の非超過確率 $F_{T}(U)$ を, 1 つの台 風時の最大風速の非超過確率 $F_{T 1}(U)$ を用いて表し， 最小自乗法によりあてはめた .ここで, 1 つの台風 時の最大風速の非超過確率 $F_{T 1}(U)$ は, Gumbel 分布 を用いた. $m$ は, 全風向の場合は年平均台風接近数, 風向別の場合は該当する風向の風を生じさせる台 風の年平均個数を表し，これらは官署毎に 50 年間 の台風経路より算出した．

$$
\begin{aligned}
& F_{T}(U)=\exp \left[-m\left\{1-F_{T 1}(U)\right\}\right] \\
& F_{T 1}(U)=\exp [-\exp \{-a(U-b)\}]
\end{aligned}
$$

式(6)，(7)より，式(8)を得る。

$$
U=b+\frac{1}{a}\left\langle-\ln \left\{-\ln \left[1+\frac{1}{m} \ln F_{T}(U)\right]\right\}\right\rangle
$$

高温季において, 台風時データと非台風時データ の両者の成因によって合成された最大風速 $U$ の非 超過確率 $F_{C}(U)$ は, 両者か互いに独立な事象とすれ ば，両者の非超過確率の積で表され，式(9)を得る . ここに, $F_{S}(U)$ は, 非台風時データの非超過確率を 表す．

$$
F_{C}(U)=F_{S}(U) F_{T}(U)
$$

上記 a)〜f)の手順によって得られた回帰式により， 全風向および各風向の再現期間風速を算出することと し，各官署における風観測データの処理を行った .

処理結果の一例として, 宮崎地方気象台における南 東風の Gumbel 確率紙上の年最大風速プロットの例を Fig.10，Fig.11に示す．Fig.10では台風時データと非

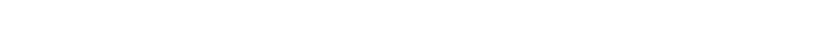
非分離のデータに良く対応していることか確認できる．

\section{3 台風シミュレーションによる風向別再現期間風} 速の算定

台風シミュレーションによって求める再現期間風 速 $V_{4}, V_{5_{-} i}$ の具体的な算出方法と炎の結果について, 以下に述べる ここで用いた台風シミュレーションは， 光田，藤井 ${ }^{12), 13)}$ の台風確率モデルを 1951〜1999 年の

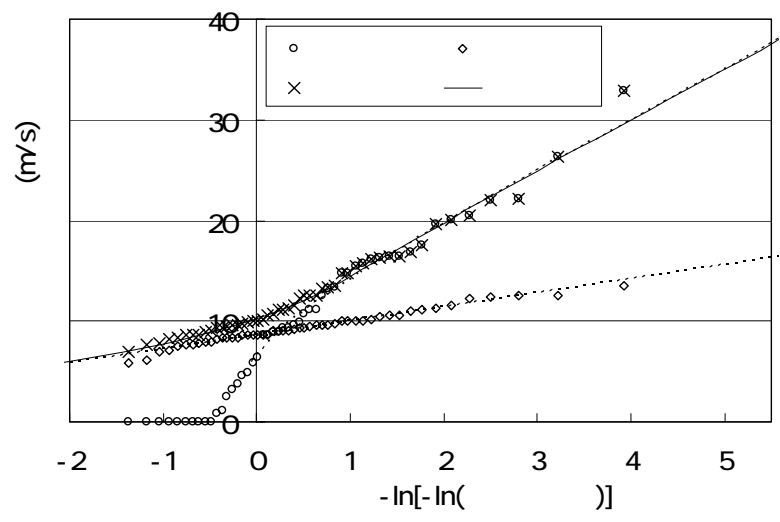

Fig.10 Gumbel 確率紙上の年最大風速プロットの例 (南東風，高温季，宮崎)

Example of annual maximum wind speeds on Gumbel probability paper(South-East wind, high temperature season, Miyazaki)

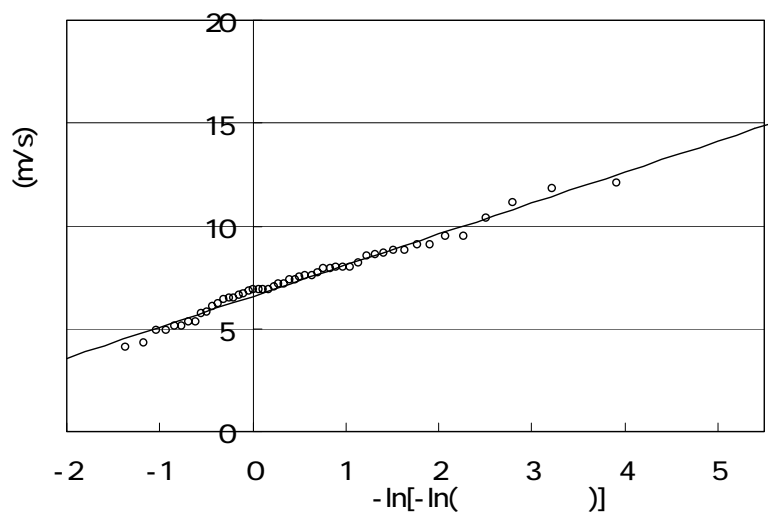

Fig.11 Gumbel 確率紙上の年最大風速プロットの例 (南東風，低温季，宮崎)

Example of annual maximum wind speeds on Gumbel probability paper(South-East wind, low temperature season, Miyazaki)

台風時の気象観測データに基づいて再評価して官署位 置における傾度風を求め, さらに傾度風と地上風の風 向相関，風速比相関を用いて地上風を算定するもので ある

（1）台風シミュレーションの概要

台風シミュレーションによって長期間の風向, 風速 データを作成する手順は以下に示す通りであり，

Fig.12 に地上風を算定する概念図を示す．

(1) シミュレーション領域の決定

(2) 台風の年間発生個数の決定

(3) 台風発生時の中心位置 (緯度, 経度) の決定

(4) 中心気圧低下量 $\Delta p$ の決定

(5) 進行速度及び進行方向の決定

(6) 最大旋衡風速半径 $r_{m}$ の決定

(7) 対象地点の傾度風の風向，風速の決定

（8）風向，風速比相関より地上風の風向，風速を算定 
上記手順で得られた官署位置における長期間の風 向・風速データに対して統計処理を行い, 8 風向別再 現期間風速を算定した .

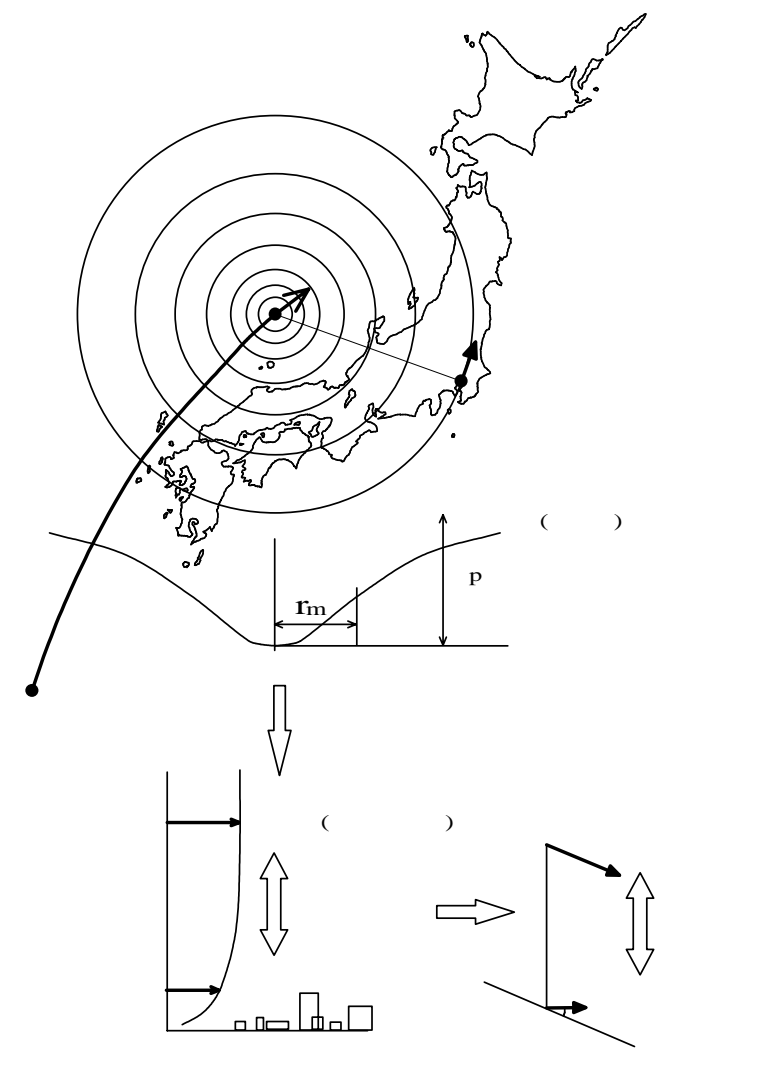

Fig.12 台風シミュレーションによる風向別風速の 算定方法

Calculation process of directional basic wind speed by typhoon simulation

\section{（2）台風パラメータの確率モデル}

台風の確率モデル作成にあたっては, 光田, 藤井の 方法 ${ }^{12), 13)}$ に従って，1951〜1999 年の台風時の気象観 測データに基づいて再評価を行った .

\section{a) 検討領域}

検討領域は, 北緯 23 度〜 43 度，東経 123 度〜147 度とし, 台風発生時および台風移動時の領域分割は, 文献 12)に従った。

b) 台風初期統計量

検討領域内に，最低中心気圧が $980 \mathrm{hPa}$ 以下で進入， あるいは $980 \mathrm{hPa}$ 以下に発達した台風数, 位置 (緯度 $\phi$ 経度 $\lambda$ ), 中心気圧低下量 $\Delta p$, 進行速度(東向き $c_{x}$, 北向き $\left.c_{y}\right)$ を求め, $\phi$ は指数分布, $\lambda$ は一樣分布,$\Delta p$, $c_{x}, c_{y}$ は対数正規分布で表すこととし，これらの確率 モデルを求めた . また，検討領域内での台風の年間発 生数の平均值は 8.1 個であり，これを平均值 8.1 のポ アソン分布で近似した .

c) 台風移動時統計量
検討領域を分割した各区ブロック内の $\Delta p, c_{x}, c_{y}$ の推移が, 前後 1 時間の值の間に, 式(10)に示す関係 があるものと仮定し，光れ光れのパラメータについて 回帰係数と誤差の標準偏差 $\sigma_{e}$ を求めた . なお, 光田, 藤井は, $\Delta p$ の時間変化量を正規分布としてモデル化 している.

$$
\begin{aligned}
& X_{\text {new }}=c_{1} X_{\text {old }}+c_{2}+e \\
& \text { こに, } \\
& X_{\text {new }}: \text { 現時点での値 } \\
& X_{\text {old }}: 1 \text { 時間前の値 } \\
& c_{1}, c_{2}: \text { 回帰係数 } \\
& e: \text { 誤差 }
\end{aligned}
$$

なお,台風シミュレーション時には, $e$ は平均值 0 , 標準偏差 $\sigma_{e}$ の正規乱数として与えることとした . d) 台風接近時の周辺気圧, 最大旋衡風速半径

最大旋衡風速半径のモデル化を行うため, 台風中心 から $100 \mathrm{~km}$ 内に官署が少なくとも1つ入り，かつ $500 \mathrm{~km}$ 圏内に 4 箇所以上の官署が入るケースを対象 として，海面気圧データを収集した .これらのデータ より, 各台風の 3 時間ごとの気圧分布を求め, Schloemer の気圧分布式の最小自乗近似により最大旋 衡風速半径 $r_{m}$ と周辺気圧 $p_{n}$ を求めた .ここでは, 周辺 気压 $p_{n}$ から中心気圧 $p_{c}$ を差し引いた気圧低下量 $\Delta p_{e}$ $\left(=p_{n}-p_{c}\right)$ を(1) $30 \mathrm{hPa}$ 末満，(2) $30 \mathrm{hPa}$ 以上 $45 \mathrm{hPa}$ 末満， (3) $45 \mathrm{hPa}$ 以上の 3 区分に分類して,$r_{m}$ を対数正規分布 でモデル化した .

（3）官署における傾度風と 観測風の風向· 風速比相関

台風接近時の官署位置における傾度風と地上風の 風向，風速比の相関モデルを作成するため，各官署を 中心として半径 $500 \mathrm{~km}$ 以内を通過した台風を抽出し， 個々の台風について 3 時間ごとの風向，風速データを 収集した . 傾度風の風向は，台風の気圧分布が同心円 状と仮定し, 台風中心から官署へ向けたベクトルに対 して直交左回りの方向とした，傾度風の風速 $V_{g r}$ は， Schloemer の気圧分布式と Blaton の公式により，台 風の移動速度を考慮して求めた .

a) 風向相関

風向相関は, 田村らの方法 ${ }^{16)}$ により求めることとし た．官署における傾度風と観測風の風向相関マトリク スの例を Table 3 に示す .なお，検討したデータは， 観測風速 $5 \mathrm{~m} / \mathrm{s}$ 以上のデータを対象とした .

台風シミュレーション時には, 地上風の風向は傾度 風向に対する地上風の出現頻度に応じ一樣乱数を用い て計算ステップ毎に求めることとした . 
Table 3 台風接近時の傾度風向に対する観測風向 (地 上風向) の発生頻度の例 (宮崎)

Correlation between observed wind direction and friction free wind direction at Miyazaki

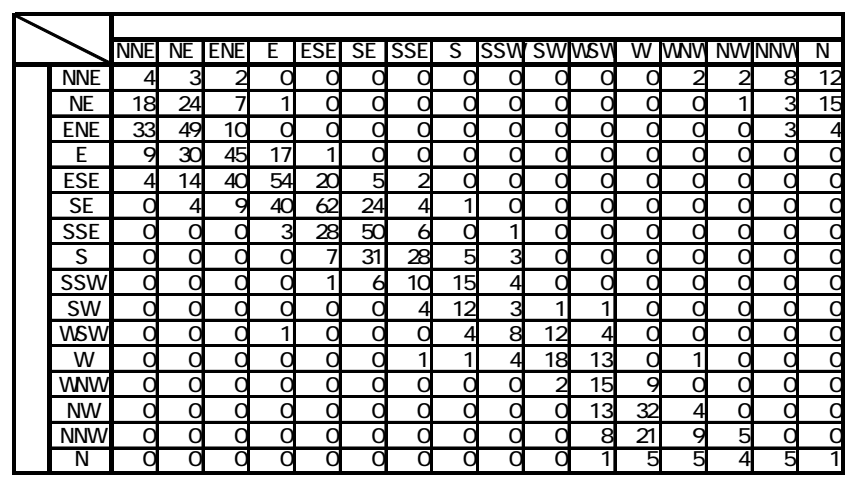

b) 風速比相関

傾度風と観測風の風速比相関を検討するにあたつ ては，観測風速が $5 \mathrm{~m} / \mathrm{s}$ 以上，かつ算定された傾度風 速が $10 \mathrm{~m} / \mathrm{s}$ 以上となる時のデータを対象とし, 風向毎 の風速比（観測風／傾度風）を利用した .なお，観測 風は，3.2 に示した風速値の補正方法により基準化し た。

官署における地上風向に対する風速比の統計量は， 地物の影響を受けやすい地上風を基準とし，隣り合う 風向を含め 3 風向分のデータを用いて算定することと した . 算定した風速比の平均值と標準偏差の例を Fig.13 に示す .

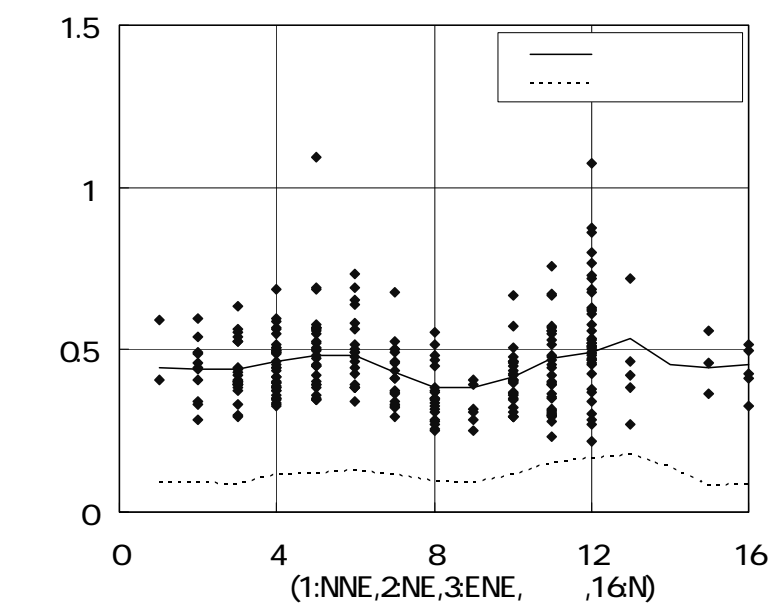

Fig.13 風速比相関の例（宮崎）

Correlation between observed wind speed and friction free wind speed at Miyazaki

台風シミュレーション時には, 地上風速の算出は, 地上風向に応じた風速比の平均値, 標準偏差を用いて 式(11)により求めることとした .

$$
V_{e}=V_{g r}\left(\sigma_{c} X+A\right)
$$

こニに，

$$
\begin{aligned}
& V_{e}: \text { 地上風速 } \\
& V_{g r}: \text { 傾度風速 } \\
& \sigma_{c}: \text { 風向別風速比の標準偏差 } \\
& A: \text { 風向別風速比の平均值 } \\
& X: \text { 標準正規乱数 }
\end{aligned}
$$

（4）台風シミュレーションによる風向別風速の算定

1951〜1999 年までの台風観測結果に基づく台風確 率モデルの検討結果，および官署における傾度風と地 上風の風向相関，風速比相関検討結果を反映した台風 シミュレーションコードを用いて，各官署における全 風向，および風向別の再現期間風速を求めた .なお， 風向相関，風速比相関は計算のステップ毎に独立に与 えることとした .

地上風の算定に際し，シミュレーション期間は 10000 年, 個々の台風の計算のステップは 1 時間とし た . また，官署と台風中心間の距離が $500 \mathrm{~km}$ 以内に 接近した場合，計算のステップは 10 分とし，官署に おける風向，風速を算定することとした．

風向別風速は，官署における風観測データの処理方 法に準じて 8 風向としてまとめ, 再現期間風速の算定 にあたっては，所定の再現期間に相当する規準化変数 の值に基づいて算定した .

計算結果として, Gumbel 確率紙上の年最大風速の プロットの例を Fig.14 に，また，Fig.15 に各官署に おける全風向の観測と台風シミュレーションの 150 年 再現期間風速の比較結果を示す .この結果より，個別 にみると多少の差異はみられるものの，両者は概ねよ く対応しているものと考えられる .なお，観測値と台 風シミュレーション結果との全風向 150 年再現期間風 速の比 (台風シミュレーション/観測) は全官署の平均 で 1.08 ，地域別で見ると，北海道 0.99 ，東北 1.20 ， 関東 1.20 ,中部 1.14 近畿 1.04 ,中国 1.05 ,四国 1.00 , 九州 0.98 , 沖縄 1.04 であった .

なお, 台風シミュレーションで用いている風速比相 関の有効デー夕数が 48 個未満 (16 風向 $\times$ 平均 3 個) と少ない官署，および風向相関・風速比相関の分布形 の偏り等により風速が算定できない風向がある官署に ついては, 台風シミュレーションの適用範囲を逸脱し ているものと判断し, 台風シミュレーションのデータ を用いないこととした . 台風シミュレーション結果を 適用しない官署を, 台風シミュレーションの適用領域 外の官署 (北緯 43 度以北の官署) とともに , Table 4 に示す。 


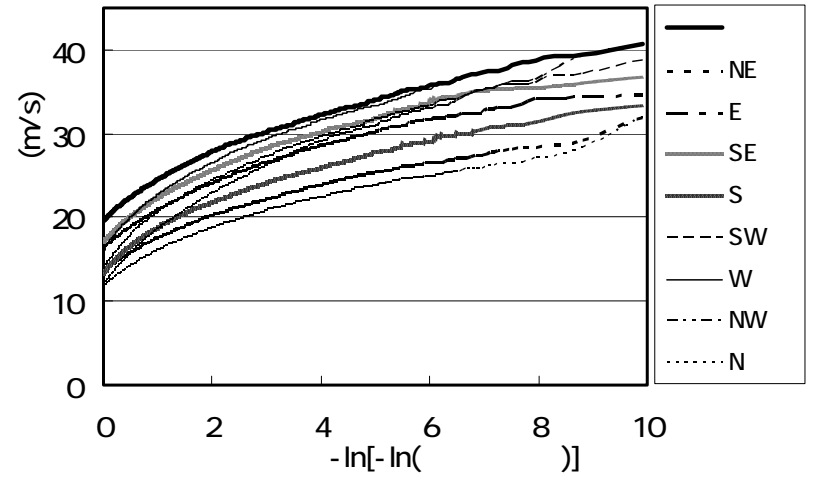

Fig.14 台風シミュレーションによる Gumbel 確率紙 上の年最大風速プロットの例 (宮崎)

Example of annual maximum wind speeds by typhoon simulation on Gumbel probability paper ( Miyazaki)

Table 4 台風シミュレーションの適用しない官署と 兴の分類

Meteorological stations which do not apply

the typhoon simulation and the categories

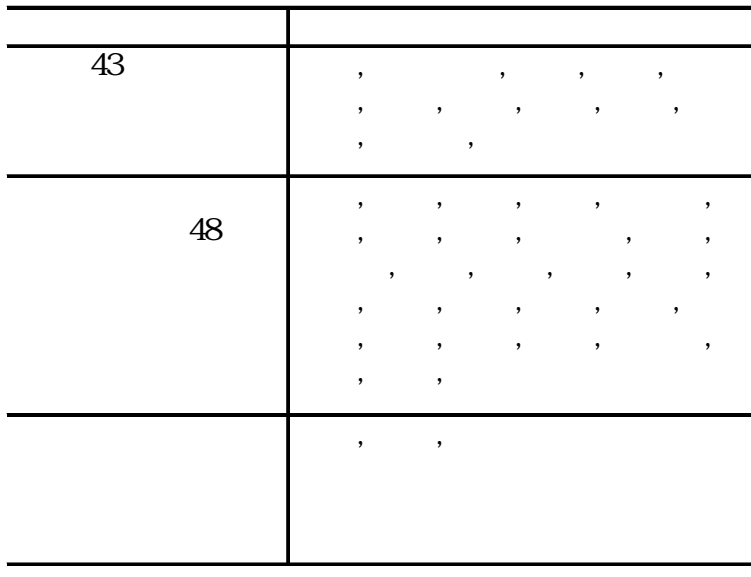

\section{4 官署位置における風向別風速算定結果と考察}

上記検討手法によって求めた官署位置における風向 別基本風速の算定例を Fig. 16 に示す .観測値のみによ って求めた值も併記した . 算定した風向別基本風速に ついて, 宮崎，千葉，高知の官署を対象に，観測值の みから求めた值との違いを示す .
(1)宮崎

官署は東側約 4〜 5km にほぼ南北に海岸線が走り， 平野部に位置している.算定した風向別基本風速は， 東西系の風速が卓越しており，観測值のみによって求 めた值に比べ, 北から西の值は最大 $10 \mathrm{~m} / \mathrm{s}$ 程度大きい 值を示した . また海から吹いてくる東風と山地から吹 いてくる西風の基本風速はほぼ同程度の値となってい る これは風速比相関の影響が反映されたものであり， 西側の主要な山地まで 10 数 $\mathrm{km}$ 離れていることから， 地形による風速比の差異が生じなかったためであると 考えられる .

(2)高知

官署から南南東の方位には約 $7 \mathrm{~km}$ 離れて東北東か ら西南西に海岸線が走り，官署の南東側には河口が存 在している. また西側から北東側 $3 \sim 5 \mathrm{~km}$ 程度以上の 領域は山岳部である . 算定した風向別基本風速は，東 から南東が卓越しており，河口に面する南系の風速が 大きく, 山岳部が存在する北西からの風速が小さくな っている．したがって，本手法によって求めた風向別 基本風速は，観測值のみによって求めた值に比べ，大 規模な地形の影響がより反映できているものと考えら れる .

\section{(3)千葉}

官署は南から北西側に湾を臨み, 平野部に位置して いる.算定した風向別基本風速は，風向によらずほぼ 一定値を示している．官署周辺に風速に影響を及ぼす 顕著な地形が存在しないことから，風向によらずほぼ 一定値を示した .一方，算定値に比べ観測值のみによ って求めた值は北東および西が $5 \mathrm{~m} / \mathrm{s}$ 程度小さくなっ ている。

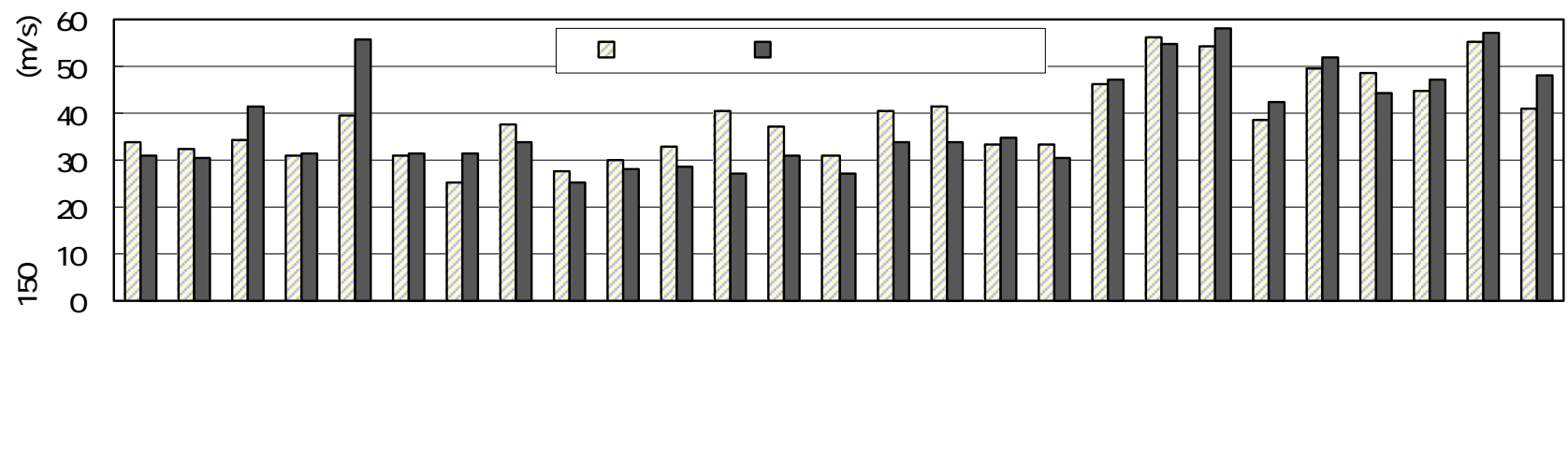

Fig.15 官署における全風向 150 年再現期間風速の比較 (九州 , 沖縄地方)

Comparison of non-directional wind speed of 150-years return period at meteorological stations 


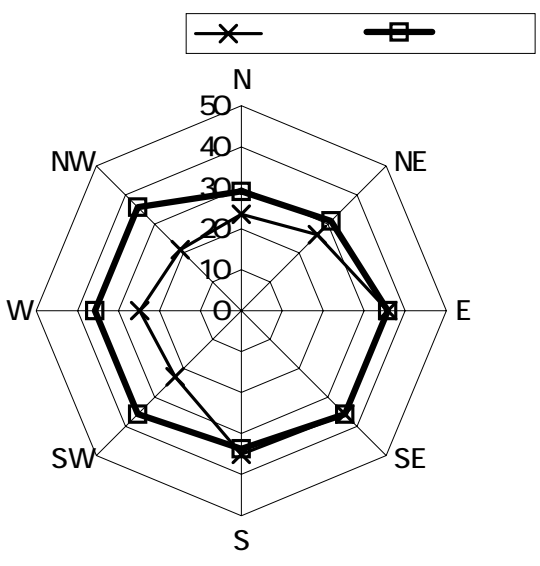

（宮 崎）

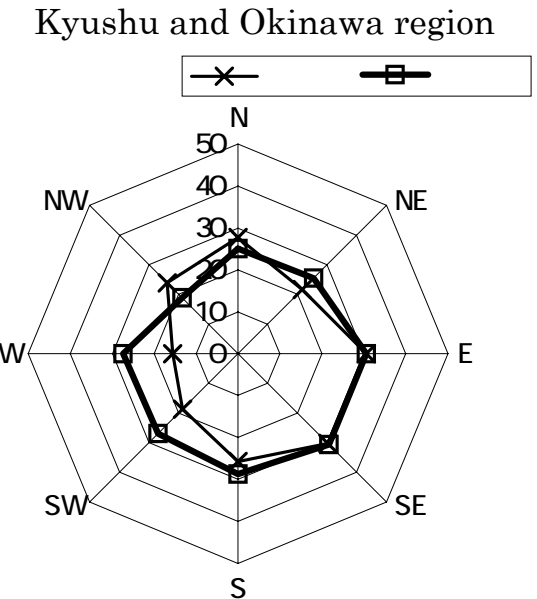

( 高 知)

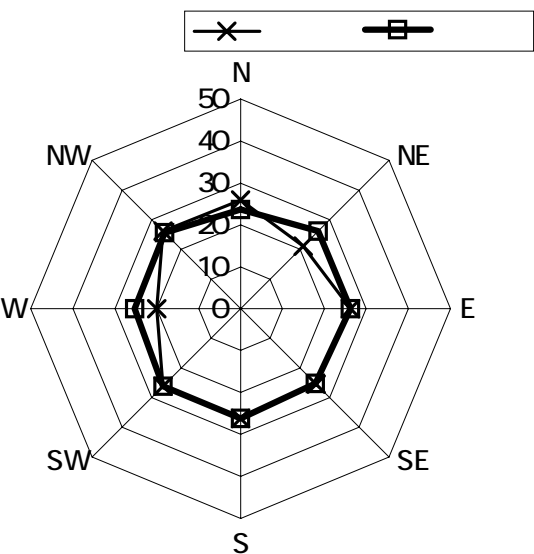

(千葉)

Fig.16 風向別基本風速の算定結果の例（高温季)

Examples of estimation results of directional basic wind (High temperature season)

以上のように, 台風シミュレーションを用いた本 手法は, 観測值のみによって求めた風向別基本風速 に比べ , データのサンプリングエラーがなく，より 実態を反映しているものと考えられる.一方，ここ で求めた風向別基本風速は，官署周辺の地域を代表 する大規模な地形の影響を反映したものとして扱っ ているが，官署によっては地形の影響だけでは説明 できないケースもみられる.今後, 地表面粗度の評 価, 地形による風向，風速プロファイルへの影響お よび台風シミュレーションなど個々の要素に対する 精度の向上を図ることか課題として挙げられる．

また, 風向別風速データの少ない官署や台風襲来 頻度の少ない地域では，今回求めた風向別基本風速 は相対的に精度が低くなっている可能性も考えられ る。

\section{4 結 論}

送電用鉄塔の合理的な設計および精緻な信頼性評 価のため, 本論文では官署における風向別基本風速 の検討を行った 得られた結論は以下の通りである .

(1)送電線の架線条件と風向別風速の分布ケースに よるパラメトリックスタディーから, 送電用鉄塔 の部材軸力の年超過確率を 0.02 とした場合 , 8 風 向別風速の再現期間として 150 年を採用するのが 妥当である.また, 全風向の 50 年再現期間風速 により上限值を設けることにより, 部材軸力の再 現期間が大きいケースについて目標とする安全 性に近づけることができ，全体としてのばらつき を抑えることが可能となることがわかった .
（2)基本風速の算定にあたっては，官署で観測された 50 年間のデータを高温季, 低温季で分類し, さら に高温季にあっては, 成因別（台風と非台風）に 整理して, 台風時データは台風シミュレーション によって得られた風速值を観測值でキャリブレー ションする手法を提案した . 本手法によって求め た風向別基本風速は, 観測值によって求めた值に 対して差異を生じるが，これはデータのサンプリ ングエラーを回避できる台風シミュレーションに よってより実態に近い值を与えたためと考えられ る。

\section{5 今後の課題}

今後の課題としては以下の点が挙げられる .

(1)風向別風速の再現期間を設定する際, Gumbel 分 布の直線の傾き $1 / a$ は代表值を用い, 風向別風速 の分布ケースは限られたものとしているが, 地点 毎，風向毎に個別に設定することにより，風向別 風速の再現期間を求めることが可能であろう.

(2)地表面粗度の評価, 地形による風向, 風速プロフ アイルへの影響，および台風シミュレーションな ど，個々の要素の精度向上を図ることか望まれる． (3)特に,台風シミュレーションの絶対値評価に対す る信頼性が向上すれば, 台風時と非台風時の風速 の確率分布を合成することで，所定の再現期間に 対する風速を求めることも可能であろう.

(4)風向別風速データの少ない官署や台風襲来頻度 の少ない地域では, 今回求めた風向別基本風速は 相対的に精度が低くなっている可能性も考えられ， 
今後も継続したデータの蓄積と評価が必要であろ j.

謝辞

本研究は, (財) 電力中央研究所が電気事業連合会 より依頼を受けて実施した「耐風設計合理化研究」 の一環として行われたものであり，本研究を実施す るに当たり，「耐風設計合理化委員会」(平成 11 年 4 月～平成 14 年 3 月 : 大熊武司委員長 (神奈川大学)) においてこ指導いただいた委員各位に深く感謝いた します．また台風シミュレーションについて, 貴重 な二意見をいただいた東京工芸大学工学部建築学科 助教授・松井正宏氏に謝意を表します.

\section{参考文献}

1)経済産業省: 電気設備技術基準・解釈，才一八社， 424 p. , 2002

2)電気学会：送電用支持物設計標準 JEC-127, 177p., 1979.

3)日本建築学会 : 建築物荷重指針・同解説， $512 \mathrm{p}$. , 1993

4)ASCE:Minimum Design Loads for Buildings and Other Structures(ASCE7-02),376p.,2002

5)Australian Standard : SAA Loading Code, Part2:Wind loads,AS 1170.2-1989,90p.,1989

6)神田順 : 風向別発生頻度を考慮した外装材用設計 風速の試案, 日本建築学会大会学術講演梗概集, pp.121-122, 1995

7)藤野陽三, 伊藤学, 田村敬一：風向を考慮した風 速統計に関する研究, 風工学シンポジウム, pp.31-38, 1982

8)松本勝, 白石成人, 白土博通, 築山有二: 風向別 強風の予測モデルと長大橋梁の耐風安全性評価へ の応用，土木学会論文集第 404 号，pp.305-314,
1989.

9)日本建築学会構造委員会荷重運営委員会 : 建築物 荷重指針改定案本文を公表し意見を問う，2002 年度日本建築学会大会 (北陸), 構造 (荷重) 部門 パネルディスカッション資料 , 69p. , 2002

10)石川智巳:送電用鉄塔の動的効果を考慮した風荷 重評価法に関する研究, 土木学会論文集, №738/ | -64, pp.139-158, 2003

11)Gomes,L. ,Vickery,B.J. : Extreme Wind Speeds in Mixed Wind Climates, Journal of Industrial Aerodynamics and Wind Engineering, 2,pp.331-344 , 1978

12)藤井健，光田寧 : 台風の確率モデルの作成と光れ による強風のシミュレイション, 京都大学防災研 究所年報, 第 29 号 B-1, pp.229-239, 1986

13)光田寧, 藤井健 : 日本南方洋上における台風の確 率モデルの作成, 京都大学防災研究所年報, 第 32 号 B-1，pp.335-348，1989

14)中村秀治,田中伸和, 中園信, 松山彰, 友延信幸 : 特殊地形における送電用鉄塔・架渉線連成系の耐 風設計に関する研究 (光の2) 特殊地形の簡易判 定法と気流シミュレーションに基づく設計風速の 算定法，日本風工学会論文集，第 82 号,pp.49-60， 2000

15)松井正宏: 構造物の耐風設計における台風モデル を用いた風速の評価と弚の応用に関する研究, 京 都大学博士論文 , 164p. , 1999

16)田村幸雄, 後藤周平, 渡辺泰志 : 台風シミュレー ションを用いた建築物の設計風速評価一風向相関 法に基づく風向係数の算定一, 構造物の安全性お よび信頼性 , JCOSSAR'95 論文集 , pp.483-486， 1995 